\title{
Contrasting effects of protection from harvesting in populations of two limpet species in a recently established marine protected area
}

\author{
CATAISA LÓPEZ ${ }^{1}$, AINOA POLADURA ${ }^{1}$, JOSÉ CARLOS HERNÁNDEZ ${ }^{1}$, LAURA \\ MARTÍN $^{2}$, LAURA CONCEPCIÓN ${ }^{2}$, CARLOS SANGIL $^{2}$ and SABRINA CLEMENTE ${ }^{1}$ \\ ${ }^{1}$ Biodiversidad, Ecología Marina y Conservación, Departamento de Biología Animal (Ciencias Marinas), Facultad de \\ Biología, Universidad de La Laguna, Av. Francisco Sánchez s/n, 38206 La Laguna, Tenerife, islas Canarias, España. \\ E-mail: kattaissa@gmail.com \\ 2 Área de Biodiversidad, Reserva Mundial de la Biosfera La Palma, Avenida Marítima 3, 38700 Santa Cruz de La Palma, \\ La Palma, Canary Islands, España.
}

\begin{abstract}
SUMMARY: This study aimed to evaluate the effects of protection from extractive activities on the population structure of two limpets of commercial interest, Patella ulyssiponensis and Patella candei crenata. We evaluated the status of these populations in La Palma Marine Protected Area (MPA), Canary Islands, and in comparable unprotected areas in the lower intertidal zone of the same island. We showed that the density of $P$. ulyssiponensis depended greatly on the level of protection, whereas the effects of protection on the density of $P$. candei crenata were less clear and only differences between sites were found. These results are probably linked to the different habitat affinities of the two species studied and demonstrate the need to tailor conservation strategies in MPAs to individual species for appropriate management of local shellfish resources.
\end{abstract}

Keywords: marine protected area, shellfishing, intertidal habitat, Patella ulyssiponensis, Patella candei crenata, Canary Islands.

\begin{abstract}
RESUMEN: DifERENTES EFECTOS DE LA PROTECCIÓN FRENTE AL MARISQUEO EN LAS POBLACIONES DE DOS ESPECIES DE LAPAS EN UNA RESERVA MARINA DE RECIENTE CREACIÓN. - Este estudio tiene por objetivo evaluar el efecto de la protección frente a actividades extractivas sobre la estructura poblacional de las especies de lapas de interés marisquero, Patella ulyssiponensis y Patella candei crenata. Para ello, se evaluó el estado de sus poblaciones en el intermareal inferior de localidades situadas tanto dentro de la Reserva Marina de La Palma (islas Canarias) como en zonas no protegidas de características similares. Se observó que la densidad de $P$. ulyssiponensis depende en gran medida del nivel de protección, mientras que en el caso de $P$. candei crenata el efecto de la protección sobre la densidad no fue tan claro, observándose diferencias sólo entre localidades. Estos resultados probablemente se relacionan con las distintas afinidades de hábitat entre las especies estudiadas, lo que indica la necesidad de proteger áreas más heterogéneas que incluyan una variedad de hábitat adecuada para la diversidad de especies de una región, asegurando una correcta regulación y conservación de los recursos marisqueros.
\end{abstract}

Palabras clave: reserva marina, marisqueo, hábitat intermareal, Patella ulyssiponensis, Patella candei crenata, islas Canarias.

\section{INTRODUCTION}

The accessibility of intertidal habitats has made fishing resources around La Palma, Canary Islands extremely susceptible to a variety of impacts caused by human harvesting of shellfish since prehistoric times (Thompson et al. 2002). While shellfish are still be- ing harvested sustainably in some locations (Kyle et al. 1997), others have been chronically impacted by this activity (Siegfried et al. 1994). The impact on these intertidal resources has increased with the growth of the human population, increasing accessibility of the coast, and use of non-traditional equipment that facilitates harvesting (Hockey and Bosman 1986, Kingsford 
et al. 1991, Underwood 1993a, Siegfried et al. 1994, Santos et al. 1995, Crowe et al. 2000). Over-collection of living intertidal resources has resulted in several types of change within shellfish populations. Changes in the mean or modal sizes of populations are widespread (Moreno et al. 1984, Hockey and Bosman 1986, Ortega 1987) because larger individuals tend to be collected more frequently (Hockey and Bosman 1986, Underwood 1993b). A number of studies also report significant reductions in target species abundances; when intensive collection occurs over a sufficiently large spatial scale, numbers can also decline as the spawning biomass decreases (Castilla and Duran 1985, Hockey and Bosman 1986).

The effect of human collection on molluscs has been described for many species in a number of studies around the world (Oliva and Castilla 1986, Duran and Oliva 1987, Ortega 1987, Hockey et al. 1988, Duran and Castilla 1989, Godoy and Moreno 1989, Keough et al. 1993). Along the coasts of the Canary Islands, harvesting of intertidal molluscs is a major fishing activity of economic importance. The increase in mollusc harvesting in recent years has had a negative effect, both directly and indirectly, on populations of some species that commonly inhabit the intertidal zone. Among target species of intertidal molluscs, patellid limpets are a resource that is in great commercial demand throughout the archipelago. In particular demand are the socalled "white limpet", Patella ulyssiponensis Gmelin, 1791, and the "black limpet", Patella candei crenata d'Orbigny 1840. The abundance of both species has declined dramatically due to a human-mediated reduction of the species' reproductive success through selective removal of the largest and most fecund individuals (Thompson et al. 2002, Brito et al. 2005a, b, Navarro et al. 2005, Ramirez et al. 2009).

A number of limpet species occupy intertidal rocky shores within the Canary Islands. Patella ulyssiponensis and $P$. candei crenata are widely distributed in the mid-low intertidal zone and in shallow subtidal areas. The two species exhibit slightly different habitat affinities, each preferring different substrate features. While $P$. ulyssiponensis is found on rocky intertidal features such as high-rugosity platforms and cobble shores, $P$. candei crenata is mainly restricted to flat surfaces of cobble beaches (Brito et al. 2008). The intertidal distribution of these species makes them vulnerable to human extraction. The level of harvesting pressure is linked to the accessibility of the coastline to humans, and differences in the degree of resource exploitation are therefore expected between sites (Thompson et al. 2002, Ramirez et al. 2009). Several measures for resource management have been proposed to mitigate the impacts of intertidal resource over-collection: for example, breeding season closures, minimum legal size for harvesting $(45 \mathrm{~mm})$ and maximum capture weight regulations (B.O.C. 2010).

Marine Protected Areas (MPAs) are specific management tools that help to prevent over-exploitation of fisheries and/or shellfish resources, by providing specific protection measures in defined areas of traditional fishing grounds. Studies in MPAs have frequently been used to help understand human-induced perturbations of ecological processes and the effects on natural populations and communities (Moreno, 2001, Clemente et al. 2011). Harvesting restrictions in MPAs result in a significant recovery of protected populations because reproductive success is enhanced and stocks therefore increase. Previous studies assessing the effects of human activities have shown that the protection measures implemented in two of the three MPAs within the Canary Islands ("Isla de La Graciosa e islotes al Norte de Lanzarote" and "La Restinga, El Hierro - Mar de Las Calmas") produced a positive response of increasing limpet population density, size and biomass (Brito et al. 2005a,b, Ramirez et al. 2009). However, no studies have yet been undertaken in the youngest MPA of the archipelago, "Isla de La Palma".

The aim of this study was to evaluate population densities and size structures in the two main species of limpets of commercial interest in La Palma island. The effects of harvesting on the structure of Patella ulyssiponensis and $P$. candei crenata populations were assessed by comparing stocks which are subject to human pressure (in unprotected areas of the intertidal zone) with those found in the Isla de La Palma MPA, where shellfish harvesting is not permitted and other activities are either restricted or prohibited. A number of anthropogenic factors were also assessed in order to examine their influence on the patellid populations. We hypothesized that the mean density and size of limpets would be lowest in non-protected sites, where fishing efforts are greater, particularly along the stretches of coastline that are most accessible to humans.

\section{MATERIALS AND METHODS}

\section{Study area}

The study was carried out at a total of eight sites along the rocky intertidal coast of La Palma island (Canary Islands) in April-September 2010. Four sites were located within La Palma MPA and four comparable sites were selected in unprotected areas along the coastline of La Palma (Fig. 1). Unprotected areas were chosen along the eastern coastline of the island, with similar environmental conditions and experiencing low wave-exposure levels (Hernández et al. 2008a) (Fig. 1).

The Canary Islands are situated at 27 to $29^{\circ} \mathrm{N}, 13$ to $18^{\circ} \mathrm{W}$, and the eastern boundary of the archipelago is separated from the coast of the African mainland by a distance of $90 \mathrm{~km}$. La Palma island is located in the northwestern part of the archipelago. La Palma MPA, established in 2001, is located on the southwestern coast of the island, and covers 3719 ha of territorial waters. This MPA comprises one central no-take area with a restricted-fishing area surrounding it (Fig. 1). In the no-take area all fishing, harvesting and scuba 


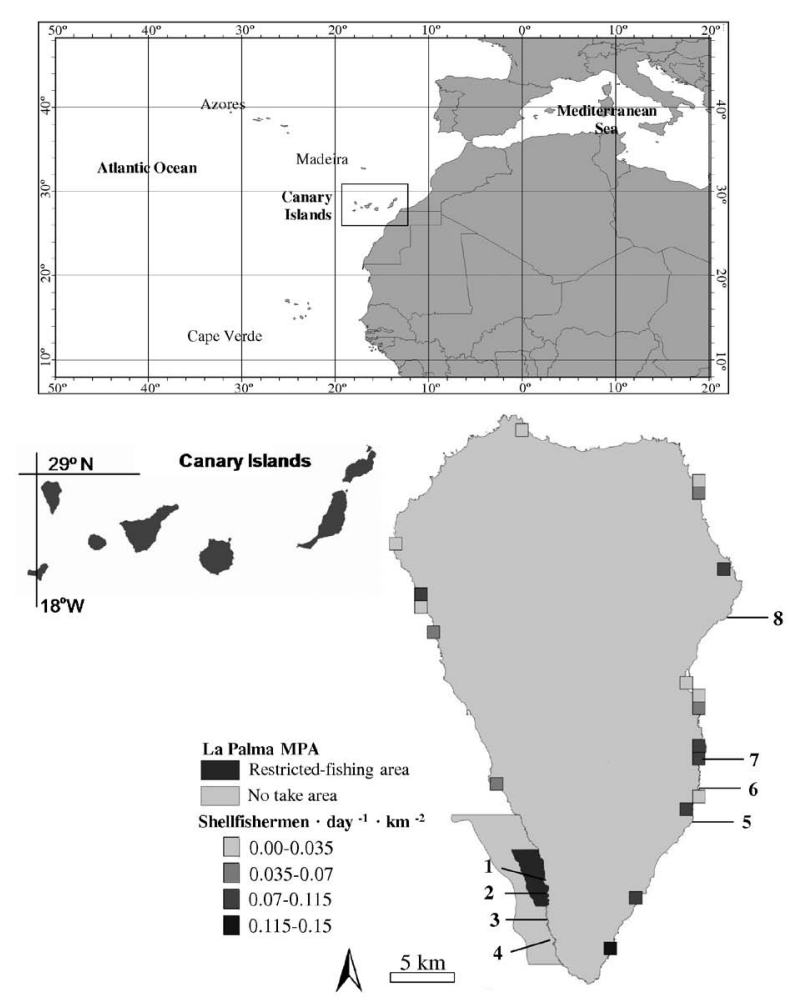

FIG. 1. - Location of study sites around La Palma island (Canary Islands), including sites within the no-take area and the restrictedfishing area of La Palma Marine Protected Area and the nearby unprotected area. Available quantitative data of shellfish harvesting pressure in unprotected areas of the island are shown (taken from Sangil et al. 2011); squares represent the mean number of shellfishermen per day at reference areas of $1 \mathrm{~km}^{2}$, recorded from March 2010 to February 2011.

diving activities are forbidden and only scientific activities are allowed. In the restricted-fishing area commercial line fishing, tunid fishing and capture of small pelagic species (to be used as fishing bait) are allowed, as well as controlled scuba diving activities (Hernández et al. 2008a). Shellfish harvesting is forbidden throughout the entire MPA, in both the intertidal and subtidal regions. Outside the MPA, limpet harvesting is allowed and shellfishing pressure has been recorded to be up to a mean of 0.15 local shellfishermen $\cdot$ day $^{-1} \cdot \mathrm{km}^{2}$ (Fig. 1), although there are certain restrictions such as a minimum legal catch size $(45 \mathrm{~mm})$, a maximum catch $(10 \mathrm{~kg}$ per harvester per day) and temporary area closures. All harvesters also need to have a valid fishing license.

The four protected sites in this study were located within the no-take and restricted-fishing areas of $\mathrm{La}$ Palma MPA on the southwestern coast and the four unprotected sites were located along the eastern side of the island on the rocky intertidal shore (Fig. 1). The sites were randomly selected but on the premise that the sites had a similar rocky intertidal habitat and were subject to similar environmental conditions: e.g. all sites experience low wave-exposure levels (Hernández et al. 2008b).

\section{Populations of patellids}

At each study site the belt transect method was used to count all individuals of the species Patella ulyssiponensis and P. candei crenata, thus providing estimates of population density for each species. We used a total of four $10 \times 2 \mathrm{~m}$ transects running parallel to the coastline using a randomly placed metric tape. At each replicate transect, observers recorded the number of individuals of each patellid species within the study area and the sizes of the individuals were measured to the nearest millimetre using calipers.

\section{Anthropogenic factors}

We assessed a number of variables as indicators of anthropogenic disturbance: human pressure, defined as the average density of inhabitants in the nearest town to a given study site (ISTAC 2009); accessibility to the coast, defined by the existence of paved/gravel roads near study sites; and coastal urbanization, defined by the presence of buildings around the sites. Accessibility (length of roads) and coastal urbanization (area occupied by buildings) were measured using orthophotos of the study area (Canary Islands topographic map: GRAFCAN 2008). Orthophotos were analysed using a geographic information system and considering an influence zone buffer of $1 \mathrm{~km}$ around the sites. The distance between study sites and the no-take area within the MPA was also calculated using an orthophoto (GRAFCAN 2008).

\section{Data analysis}

A multivariate comparison of the density of the two limpet species was conducted using a distance-based permutational multivariate analysis of variance (PERMANOVA) (Anderson 2001), to compare the structure of patellid assemblages between protection levels (MPA and non-protected areas) and sites. Speciesspecific analyses were conducted to contrast patellid population densities and sizes with distance-based permutational ANOVAs (Anderson 2001) performed separately for each limpet species. Analyses were conducted using Bray Curtis dissimilarity measures (for the PERMANOVA) and Euclidean distances (for ANOVAs) of raw data respectively, with all $P$-values obtained using 4999 permutations of the appropriate exchangeable units. We used two-way designs in which the factor "Protection" was fixed (2 levels) and the factor 'Site' was random and nested within Protection (8 levels). The statistical software PRIMER 6 \& PERMANOVA+ (www.primer-e.com) was used to conduct these procedures.

We analysed the effect of protection on the size structure of Patella ulyssiponensis and P. candei crenata by means of size-frequency analyses $\left(\chi^{2}\right)$ that compared limpet populations in the MPA and unprotected areas using the SPSS 15.0 statistical software. 
TABLE 1. - Results of the two-way distance-based permutational multivariate analyses of variance (PERMANOVA) assessing differences in abundance between the marine protected area and unprotected areas at La Palma Island, and sites studied within each protection level in two limpet species of commercial interest, Patella ulyssiponensis and Patella candei crenata.

\begin{tabular}{lccccc}
\hline Source of variation & df & SS & MS & \multicolumn{2}{c}{ Pseudo-F $P($ perm) } \\
\hline Protection & 1 & 17578.00 & 18082.00 & 5.47 & $<0.05$ \\
Site (Protection) & 6 & 2632.40 & 3331.00 & 3.70 & $<0.01$ \\
\hline
\end{tabular}

Anthropogenic factors (human pressure, accessibility to the coast and coastal urbanization) and the distances of sampling sites from the no-take area of La Palma MPA were compared against mean densities and sizes for both limpet species using regression analyses in SPSS-15.0.

\section{RESULTS}

\section{Patellid assemblages}

The PERMANOVA analysing density and composition of patellid assemblages revealed significant differences between protection levels and study sites in both the MPA and the non-protected area (Table 1). Overall densities of patellids were higher at sites within the MPA than at non-protected sites (Table 2, Fig. 2). The maximum densities of both Patella ulyssiponiensis $\left(3.44 \pm 2.58\right.$ ind. $\left.\mathrm{m}^{-2}\right)$ and Patella candei crenata $\left(3.34 \pm 1.11\right.$ ind. $\left.\mathrm{m}^{-2}\right)$ were registered within the MPA, while the minimum mean densities were recorded at non-protected sites of the island $(0.16 \pm 0.06$ and $0.02 \pm 0.04$ ind. $\mathrm{m}^{-2}$ for each species respectively)

TABle 2. - Descriptive statistics of size and density of limpet species Patella ulyssiponensis (P.u.) and Patella candei crenata (P.c.) at study sites (1-8) within La Palma Marine Protected Area (MPA) and nearby unprotected area (UA) off La Palma island. Sampling size (N) is given for each species. Mean, standard error (SE), maximum (Max) and minimum (Min) values are given for body size; mean and SE are shown for density of the species. Total mean and standard error (SE) of patellids, including both species, are given for both variables at each site.

\begin{tabular}{|c|c|c|c|c|c|c|c|c|c|}
\hline & Site & Patellid sp. & $\mathrm{N}$ & & & & & & \\
\hline & & & & Mean & SE & Max & Min & Mean & SE \\
\hline MPA & 1 & P.u. & 104 & 32.79 & 8.91 & 61 & 13 & 1.30 & 0.81 \\
\hline & & P.c. & 18 & 26.44 & 8.79 & 51 & 16 & 0.23 & 0.20 \\
\hline & & Total & 122 & 31.85 & 9.14 & & & 0.80 & 0.79 \\
\hline & 2 & P.u. & 89 & 51.89 & 13.45 & 78 & 21 & 1.11 & 0.57 \\
\hline & & P.c. & 267 & 41.61 & 10.06 & 71 & 15 & 3.34 & 1.11 \\
\hline & & Total & 356 & 44.18 & 11.85 & & & 2.20 & 1.44 \\
\hline & 3 & P.u. & 275 & 29.93 & 8.11 & 55 & 11 & 3.44 & 2.58 \\
\hline & & P.c. & 124 & 32.77 & 8.07 & 60 & 11 & 1.55 & 0.97 \\
\hline & & Total & 399 & 30.81 & 8.19 & & & 2.50 & 2.07 \\
\hline & 4 & P.u. & 119 & 36.89 & 7.76 & 55 & 16 & 1.49 & 0.41 \\
\hline & & P.c. & 72 & 41.89 & 9.21 & 59 & 18 & 0.90 & 0.12 \\
\hline & & Total & 191 & 38.77 & 8.66 & & & 1.20 & 0.42 \\
\hline UA & 5 & P.u. & 23 & 28.50 & 8.07 & 42 & 9 & 0.23 & 0.08 \\
\hline & & P.c. & 19 & 33.32 & 6.24 & 41 & 16 & 0.19 & 0.11 \\
\hline & & Total & 42 & 30.68 & 7.61 & & & 0.20 & 0.10 \\
\hline & 6 & P.u. & 66 & 30.77 & 10.66 & 52 & 11 & 0.66 & 0.42 \\
\hline & & P.c. & 29 & 37.28 & 5.12 & 46 & 23 & 0.29 & 0.28 \\
\hline & & Total & 95 & 32.76 & 9.77 & & & 0.50 & 0.39 \\
\hline & 7 & P.u. & 69 & 24.45 & 7.50 & 46 & 10 & 0.76 & 0.58 \\
\hline & & P.c. & 34 & 23.76 & 6.56 & 39 & 10 & 0.02 & 0.04 \\
\hline & & Total & 103 & 24.22 & 7.18 & & & 0.40 & 0.55 \\
\hline & 8 & P.u. & 13 & 26.65 & 8.06 & 41 & 15.5 & 0.16 & 0.06 \\
\hline & & P.c. & 72 & 24.91 & 9.94 & 47 & 6 & 0.93 & 1.12 \\
\hline & & Total & 85 & 25.18 & 9.66 & & & 0.50 & 0.84 \\
\hline
\end{tabular}

TABLE 3. - Results of the two-way, distance-based permutational analyses of variance (ANOVA) assessing differences between the marine protected area and the unprotected area at La Palma island and sites within each protection level for (a) density and (b) body size data of the limpets of commercial interest Patella ulyssiponensis (P.u.) and Patella candei crenata (P.c.). [ns, not significant].

\begin{tabular}{|c|c|c|c|c|c|c|c|}
\hline & Patellid sp. & Source of variation & df & SS & MS & Pseudo- $F$ & $P($ perm $)$ \\
\hline \multirow[t]{4}{*}{ (a) Density } & P.u. & Protection & 1 & 16.98 & 16.98 & 6.81 & $<0.05$ \\
\hline & & Site (Protection) & 6 & 15.04 & 2.51 & 2.62 & $<0.05$ \\
\hline & P.c. & Protection & 1 & 10.01 & 10.02 & 2.67 & ns \\
\hline & & Site (Protection) & 6 & 22.70 & 3.78 & 8.74 & $<0.01$ \\
\hline \multirow[t]{4}{*}{ (b) Size } & P.u. & Protection & 1 & 9297.8 & 9297.8 & 3.11 & ns \\
\hline & & Site (Protection) & 6 & 34785 & 5797.4 & 69.42 & $<0.01$ \\
\hline & P.c. & Protection & 1 & 6765.3 & 6765.3 & 4.46 & $\mathrm{~ns}$ \\
\hline & & Site (Protection) & 5 & 10510 & 2102 & 23.57 & $<0.01$ \\
\hline
\end{tabular}




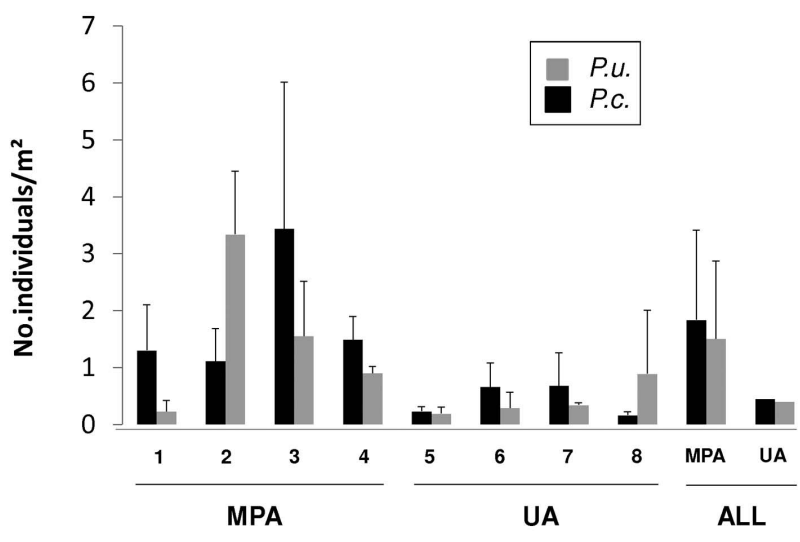

FIG. 2. - Mean density ( \pm SE) of Patella ulyssiponensis (P.u.) and Patella candei crenata (P.c.) within study sites (1-8) in La Palma Marine Protected Area (MPA) and the unprotected area (UA). Total densities of both species in the MPA and UA are also given.

(Table 2). Maximum limpet sizes were also recorded at sites inside the MPA, with $P$. ulyssiponiensis reaching a mean size of $51.89 \pm 13.45 \mathrm{~mm}$ and $P$. candei crenata reaching a mean size of $41.89 \pm 9.21 \mathrm{~mm}$ (Table 2, Fig. 3 ). At non-protected sites maximum species sizes were $30.77 \pm 10.66 \mathrm{~mm}$ for $P$. ulyssiponiensis and $37.28 \pm 5.12$ $\mathrm{mm}$ for $P$. candei crenata (Table 2, Fig. 3 ).

\section{Populations of Patella ulyssiponensis and $\boldsymbol{P}$. candei crenata}

Considering each limpet species separately, permutational ANOVA results showed that for Patella ulyssiponensis population density differed significantly between levels of protection and sites studied (Table 3 ). Higher mean densities of the species were found in the MPA than in non-protected areas (Fig. 2). In the $P$. candei crenata population, only site had a significant effect on the species' population densities (Table 3). No significant effect of protection level was obtained, despite the general trend of higher limpet densities at sites within the MPA (Table 2, Fig. 2).

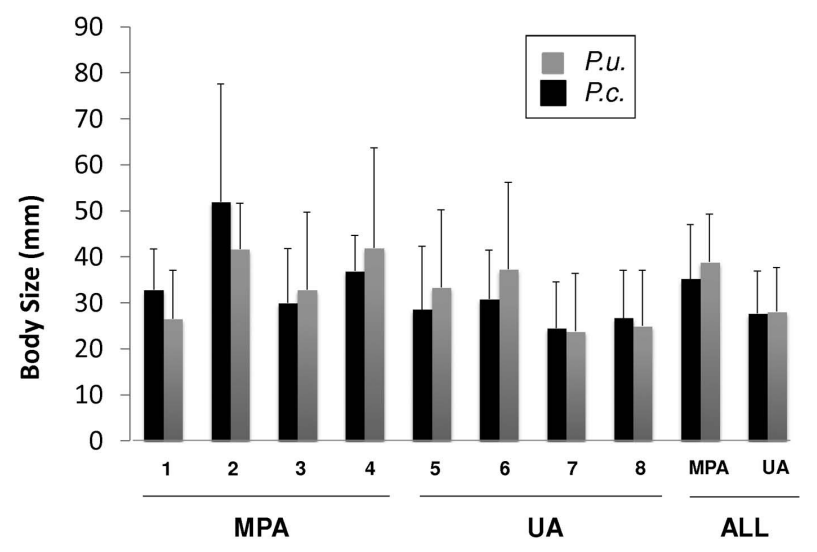

Fig. 3. - Mean body size $( \pm$ SE) of Patella ulyssiponensis (P.u.) and Patella candei crenata (P.c.) within study sites (1-8) in La Palma Marine Protected Area (MPA) and the unprotected area (UA). Overall body sizes registered for both species at MPA and UA are given.

No significant differences in mean sizes of patellids were recorded between protection levels for either species (Table 3), although limpet sizes tended to be larger within the MPA (Fig. 3). In both species, there were significant differences between sites within each protection level (Table 3 ).

Size-frequency analysis $\left(\chi^{2}\right)$ for $P$. ulyssiponiensis and $P$. candei crenata showed significant differences in size distributions of populations of both species between protection levels $\left(\chi^{2}=64,333, \mathrm{p}<0.001\right.$ and $\chi^{2}=118,173, \mathrm{p}<0.001$, respectively). The size distribution of both patellids followed a unimodal pattern within the MPA and non-protected area, although modal sizes for both species were larger in the MPA than at the non-protected sites (Fig. 4).

\section{Anthropogenic factors}

Population densities of $P$. ulyssiponensis were influenced by the distance of study sites from the notake area of La Palma MPA (Fig. 5A) and by human pressure (Fig. 6A). There was a negative exponential
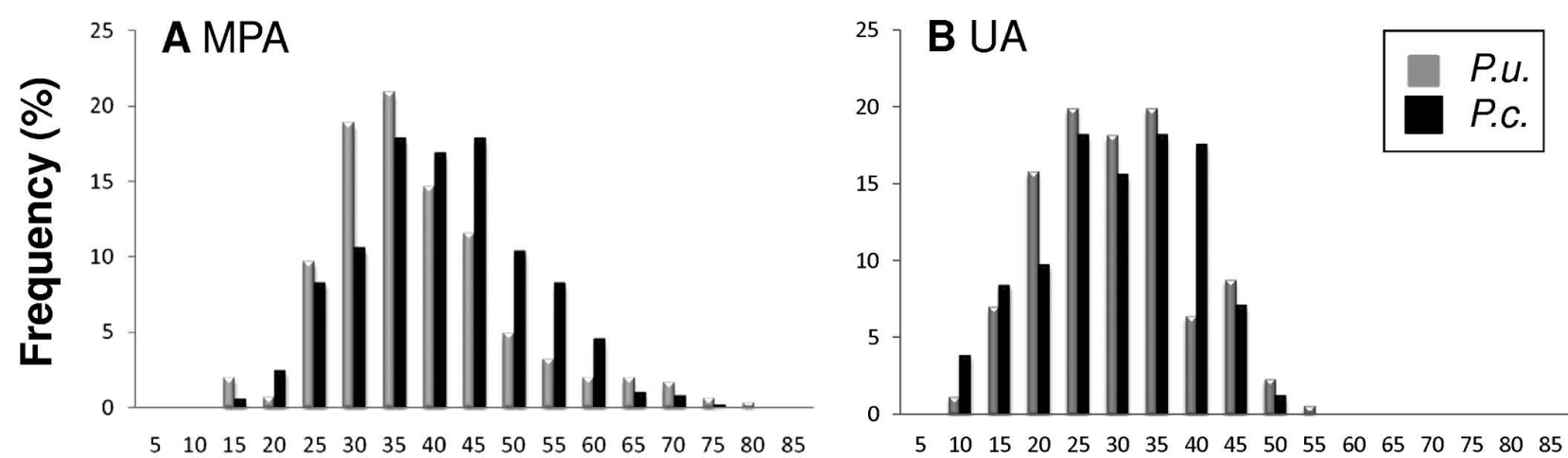

\section{Size $(\mathrm{mm})$}

FIG. 4. - Size-frequency distribution of the populations of Patella ulyssiponensis (P.u.) and Patella candei crenata (P.c.) in (A) La Palma Marine Protected Area (MPA) and (B) the unprotected area (UA). 

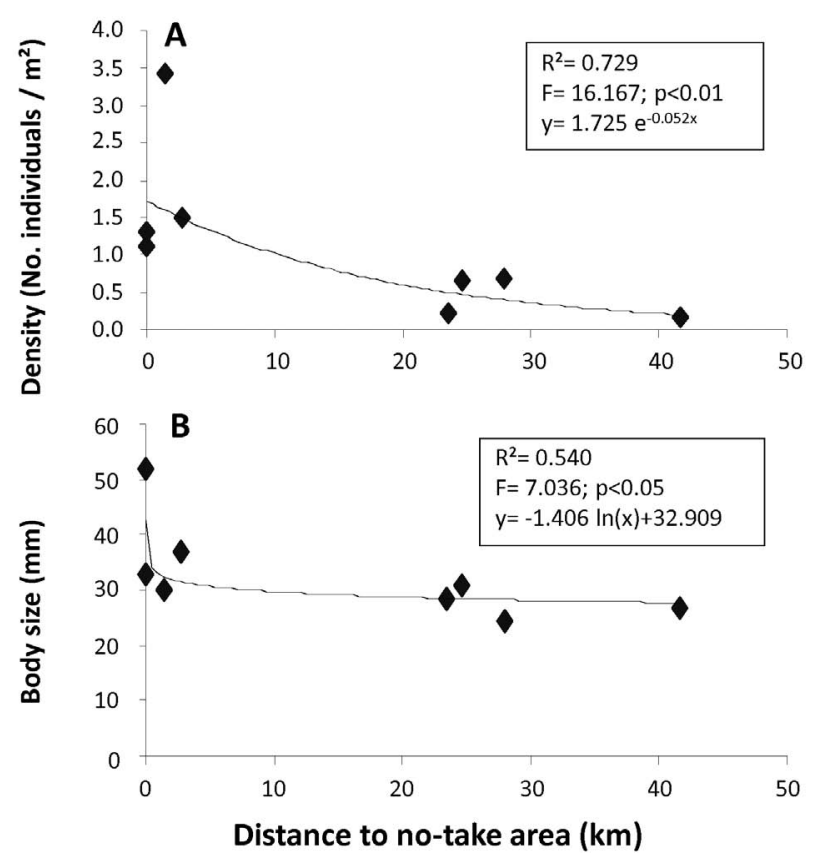

FIG. 5. - Regression models of the distance from study sites to the no-take area of La Palma Marine Protected Area and (A) mean population densities and (B) mean body size of Patella ulyssiponensis.

relationship between anthropogenic factors and mean limpet density, gradually decreasing with distance from the no-take area (Fig. 5a) and with increasing numbers of inhabitants at study sites (Fig 6a). P. ulyssiponensis body size was also significantly influenced by the distance from the no-take area, with a significant negative logarithmic relationship between the two variables (Fig. 5b), and by a negative potential relationship with coastal urbanization at sampling sites (Fig 6b). There were no significant effects of the other studied anthropogenic disturbance factors on $P$. ulyssiponensis density (accessibility to the coast: $R^{2}=0.001, F=0.003$, $\mathrm{p}=0.957$; coastal urbanization at sampling sites: $R^{2}=0.061, F=0.388, P=0.556$ ) and body size (accessibility to the coast: $R^{2}=0.018, F=0.110$, p=0.752; human pressure: $\left.R^{2}=0.406, F=4.108, \mathrm{p}=0.089\right)$.

No significant effects of anthropogenic disturbance factors were detected on Patella candei crenata populations, such as distance of study sites from the no-take area $\left(R^{2}=0.207, F=1.564, \mathrm{p}=0.258\right.$ and $R^{2}=0.274, F=2.259$, $\mathrm{p}=0.184$ for density and size respectively), numbers of inhabitants $\left(R^{2}=0.292, F=2.480, \mathrm{p}=0.166\right.$ and $R^{2}=0.186$, $F=1.368$, p $=0.286$ for density and size respectively), accessibility of the coast $\left(R^{2}=0.018, F=0.108, \mathrm{p}=0.754\right.$ and $R^{2}=0.399, F=3.958, \mathrm{p}=0.093$ for density and size respectively), and coastal urbanization at sampling sites $\left(R^{2}=0.135, F=0.940, \mathrm{p}=0.370\right.$ and $R^{2}=0.302, F=2.595$, $\mathrm{p}=0.158$ for density and size, respectively).

\section{DISCUSSION}

In the marine environment, fishing activities have historically targeted intertidal resources because these
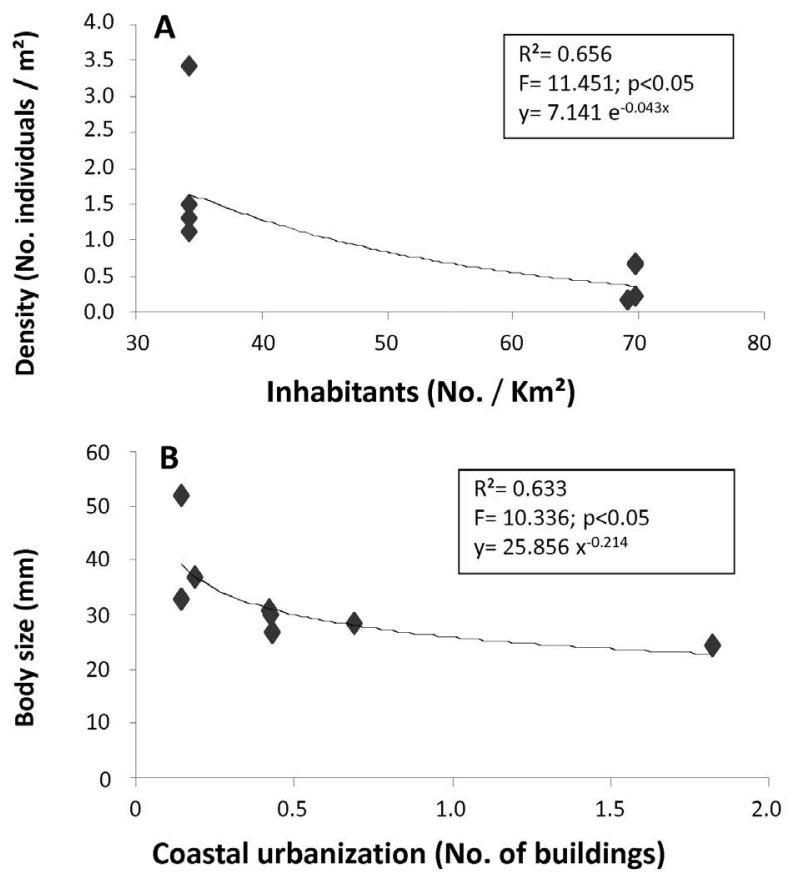

FIG. 6. - Regression models of (A) human pressure (number of inhabitants per $\mathrm{km}^{2}$ ) and (B) coastal urbanization (number of buildings) with mean population densities and body size of Patella ulyssiponensis, respectively.

habitats are more accessible, in many cases leading to severe population declines (Castilla and Duran 1985, Jamieson 1993, Roy et al. 2003, Martins et al. 2008) and alterations to the equilibrium of ecosystems. Fishing and harvesting restrictions implemented in MPAs have allowed studies that help us understand and mitigate the effect of human activities on commercial species (Pinnegar et al. 2000). MPAs also provide an opportunity to test how natural forces, such as intra- and inter-specific competition, interact with anthropogenic impacts in shaping marine ecosystems (Micheli et al. 2005). They have revealed worldwide that putting in place protection measures can significantly increase the abundance and size of many economically important species (see review by García-Charton et al. 2008), with some species responding more positively to protection measures than others.

The patellid species Patella ulyssiponensis and $P$. candei crenata are highly prized fishing resources in both local recreational and commercial fisheries across the Canary Islands (Brito et al. 2005a, b, Ramirez et al. 2009). Both species inhabit the intertidal rocky shore of the Canary Islands, achieving maximum population densities in the mid-shore range (Hawkins et al. 1990, Martins et al. 2008). However, our results suggest that $P$. ulyssiponensis is generally more abundant than $P$. candei crenata in intertidal habitats. This difference between species could be due to natural processes mediated by inter-specific competition (Boaventura et al. 2003) or related to the different habitat affinities of the two species. While P. ulyssiponensis is currently found at a wide range of mid-intertidal habitats, $P$. can- 
dei crenata has a more restricted habitat and is mainly found in the mid-shore ranges of cobble beaches (Brito et al. 2008). Management strategies should consider differences between the species in order to assist in effective conservation of target populations.

Harvesting licenses, minimum legal sizes based on biological characteristics, and maximum quotas are conservation strategies that are currently implemented to increase the sustainability of intertidal resources within the Canary Islands. However, the rapid growth of human populations has increased perturbation of marine species as resources are increasingly harvested for food and recreational purposes, rendering existing conservation strategies highly insufficient. MPAs are therefore an alternative strategy for the management of shellfishing resources. For several measured variables, our results indicated that protection in the MPA had a positive effect on populations of $P$. ulyssiponensis and $P$. candei crenata. The benefits of protection were more clearly seen in population densities of $P$. ulyssiponensis, whereas results from $P$. candei crenata were more variable and site-specific, though a trend of increasing densities of the species within the proximity of the no-take area was clearly seen. It is possible that the recovery of $P$. candei crenata populations may be limited because the species has more restricted habitat requirements than $P$. ulyssiponensis, although other site-specific features may be influencing the variability found in abundances at smaller spatial scales. These results highlight the need to protect heterogeneous stretches of coastline containing habitats suitable for a diverse range of species, although the environmental factors potentially controlling populations at smaller scales should be addressed in further studies.

Contrary to our predictions, the protection offered by the MPA did not significantly affect the mean size of either species. The two limpets showed clear signs of stock over-exploitation, with mean sizes below the minimum legal size $(45 \mathrm{~mm})$ at most study sites, both inside and outside the MPA. The lack of clear effects of protection on limpet sizes may be related to a reduced growth of specimens at low-productivity sites such as the ones studied at La Palma. A larger time span would be needed to allow new recruits to grow beyond the minimum legal size in the MPA and to detect an effect of protection on mean sizes. However, the effects of harvesting regulations were seen in the size-frequency distributions of both species, probably due to the size selective collection of these intertidal resources at unprotected sites (Ramirez et al. 2009). Populations showed depletion of large sizes in unprotected areas, where the maximum size of any individual limpet was $52 \mathrm{~mm}$ for $P$. ulyssiponensis and $47 \mathrm{~mm}$ for $P$. candei crenata, in comparison with $78 \mathrm{~mm}$ and $71 \mathrm{~mm}$, respectively within the MPA. The selection bias towards larger sizes is a direct consequence of anthropogenic impacts, previously noted in other regions of the $\mathrm{Ca}-$ nary Islands (Navarro et al. 2005, Ramírez et al. 2009) and elsewhere for other molluscs (e.g. Keough et al.
1993, Ferraz et al. 2001, Roy et al. 2003, Branch and Odendaal 2003, Sagarin et al. 2007). The removal of mature animals is likely to cause major ecological disturbance due to the consequent reduction in reproductive output of the resident population. Oceanic island environments may be more susceptible to removal of these megaspawners owing to a higher isolation of populations, which may render island populations more vulnerable to exploitation than elsewhere (Roberts and Hawkins 1999). Over time populations are being progressively 'fished down' (Moreno 2001, Martins et al. 2008), causing severe changes in population structure and an overall reduction in the density and size frequency of the resource. Previous studies in the Canary Islands have shown that intense exploitation of intertidal limpets leads to a dramatic reduction, and even local extinction, of populations of $P$. cande $i$ crenata (Côrte-Real et al. 1996, Navarro et al. 2005). This previous knowledge and the fact that protection at the MPA only partially improved the health of the patellid populations studied highlights the need for development of more appropriate management of these species.

In our study, the effects of extractive activities on the population structure of two target species was evident not only in a reduction of large-sized limpets but also in a depletion of the number of specimens in most size ranges. Similar studies from the eastern Canarian Archipelago, comparing sites at La Graciosa MPA with unprotected sites, showed that human pressure had a significant effect on limpet populations (Brito et al. 2005a, b, Ramirez et al. 2009) and that populations recovered following protection. No previous studies had assessed the status of limpet populations in the most recently established MPA in the Canarian archipelago: La Palma. The results presented here, less than ten years after the establishment of this MPA, suggest that the no-take area is proving effective in aiding the recovery of stocks of intertidal resources. However, more should be done to protect the least responsive of the two species, $P$. candei crenata, and species-specific management strategies should be implemented. For example, different maximum quotas could be set for individual species, or bedrocks and cobble shore habitats especially favourable for $P$. candei crenata could be the focus of protection. Integrating these priorities in the design of an MPA can sometimes be difficult because there are a number of species to consider, each with a different habitat affinity. The delimitation of areas specifically aimed at protecting shellfish resources could be a worthy alternative, especially in regions such as the Canary Islands where few intertidal species are of commercial interest.

In conclusion, this study suggests that the survival of key commonly harvested herbivores is highly correlated with human disturbance in the Canary Islands. In the establishment of protection measures in MPAs, the different habitat affinities of target species should be considered in order to effectively protect stretches of 
coast where populations of several target species have the potential to re-establish.

\section{ACKNOWLEDGEMENTS}

We are grateful to A. Glocker and A. Díaz, who helped in field surveys. C.L. and S.C. were funded by the project "Proyecto Estructurante en Ciencias Marinas" from the "Agencia Canaria de Investigación, Innovación y Sociedad de la Información”.

\section{REFERENCES}

Anderson M.J. 2001. A new method for non-parametric multivariate analysis of variance. Austral. Ecol., 26: 32-46.

Boaventura D., Da Fonseca L. C., Hawkins S. J. 2003. Size matters: competition within populations of the limpet Patella depress. $J$. Anim. Ecol. 72(3): 435-446.

B.O.C. 2010. Orden de 5 de Julio de 2010, por la que se regula temporalmente el marisqueo professional a pie, para la recolección de lapas. Boletín Oficial de Canarias. 132(7-7-2010): 17456-17457.

Branch G.M., Odendaal F. 2003. The effects of marine protected areas on the population dynamics of a South African limpet, Cymbula oculus, relative to the influence of wave action. Biol. Conserv. 114(2): 255-269.

Brito A., Barquín J., Falcón J.M., González G., Clemente S., Hernández J.C. Toledo K. Sangil C., Rodríguez A., Martín L. 2005a. Seguimiento de la reserva de El Hierro y estudio de recursos marisqueros, Viceconsejería de Pesca del Gobierno de Canarias. Universidad de La Laguna. $75 \mathrm{pp}$

Brito, A. Barquín, J., Falcón, J.M., González, G., Clemente, S., Hernández, J.C., Toledo, K., C. Sangil, Rodríguez, A., Martín, L. 2005b. Valoración in situ de las poblaciones de especies indicadoras del efecto reserva en la Reserva Marina de La Graciosa y los islotes del norte de Lanzarote. Viceconsejería de Pesca del Gobierno de Canarias. Universidad de la Laguna, 105 pp.

Brito A., González J.A. , Tuset V.M., Quiles J.A., González-Lorenzo G., Girard D., Toledo K., González E., García-Mederos A.M., Ayza O., Arrasate-López M., Pérez-Peñalvo J.A., Santana J.I. 2008. Estudio científico de evaluación y parámetros biológicos de especies marisqueras intermareales. $1^{\text {a }}$ Parte. Viceconsejería de Pesca del Gobierno de Canarias. Universidad de La Laguna, 83 pp.

Castilla J.C., Duran L.R. 1985. Human exclusion from the rocky intertidal zone of Central Chile - the effects on Concholepas concholepas (Gastropoda). Oikos 45: 391-399.

Côrte-Real H.B.S.M., Hawkins S.J, Thorpe J.P. 1996. Population differentiation and taxonomic status of the exploited limpet Patella candei in the Macaronesian islands (Azores, Madeira, Canarias). Mar. Biol. 125: 141-152.

Clemente S., Hernández J.C., Brito A. 2011. Context-dependent effects of marine protected areas on predatory interactions. Mar. Ecol. Progr. Ser. 437: 119-133.

Crowe T.P., Thompson, R.C., Bray, S. and Hawkins, S.J. 2000. Impacts of anthropogenic stress on rocky intertidal communities. J. Aquat. Ecosyst. 7: 273-297.

Duran L.R., Castilla J.C. 1989. Variation and persistence of the middle rocky intertidal community of central Chile, with and without human harvesting. Mar. Biol. 103: 555-562.

Duran L.R., Oliva D. 1987. Intensity of human predation on rocky shores at Las Cruces in Central Chile. Environ. Conserv. 14: 143-149.

Ferraz R.R., Menezes G.M., Santos R.S. 2001. Limpet (Patella spp.) (Mollusca: Gastropoda) exploitation in the Azores, during the period 1993-1998. Arquipel. Life Mar. Sci. 2 (B): 59-65.

García-Charton J.A., Pérez-Ruzafa A., Marcos C., Claudet, Badalamenti F., Benedetti-Cecchi L., Falcón J.M., Milazzo M., Schembri P.J., Stobart B., Vandeperre F., Brito A., Chemello R., Dimech M., Domenici P., Guala I., Le Diréach L., Maggi E., Planes S. 2008. Effectiveness of European Atlanto-Mediterranean MPAs: Do they accomplish the expected effects on populations, communities and ecosystems? J. Nat. Conserv. 16: 193-221.
Godoy C., Moreno C.A. 1989. Indirect effects of human exclusion from the rocky intertidal in southern Chile: a case of crosslinkage between herbivores. Oikos 54: 101-106.

GRAFCAN. 2008. Mapa Topográfico de Canarias. La Palma. 2008. Grafcan, Consejería de Política Territorial y Medio Ambiente. Gobierno de Canarias. http://www.grafcan.es/

Hawkins S.J., Burnay L.P., Neto A.I., Tristão da Cunha R., de Frias Martins A.M. 1990. A description of the zonation patterns of molluscs and other important biota on the South coast of São Miguel, Azores. In: de Frias Martins A.M. (ed.), Proceedings of the First International Workshop of Malacology, São Miguel, Açores, 1988, The Marine Fauna and Flora of the Azores. Açoreana, 2: 21-38.

Hernández J.C., Clemente S., Sangil C., Brito A. 2008a. Actual status of the sea urchin Diadema aff. antillarum populations and macroalgal cover in marine protected areas compared to a highly fished area (Canary Islands - eastern Atlantic Ocean). Aquat. Conserv. Mar. Freshw. Ecosyst. 18: 1091-1108.

Hernández J.C., Clemente S., Sangil C., Brito A. 2008b. The key role of the sea urchin Diadema aff. antillarum in controlling macroalgae assemblages throughout the Canary Islands (eastern subtropical Atlantic): a spatio-temporal approach. Mar. Environ. Res. 66: 259-270.

Hockey P.A.R., Bosman AL. 1986. Man as an intertidal predator in Transkei: disturbance, convergence and management of a natural food resource. Oikos 46: 3-14.

Hockey P.A.R., Bosman A.L. and Siegfried W.R. 1988. Patterns and correlates of shellfish exploitation by coastal people in Transkei: an enigma of protein production. J. Appl. Ecol. 25: 353-363.

ISTAC. 2009. Instituto Canario de Estadística. http://www.gobiernodecanarias.org/istac/

Jamieson G.S. 1993. Marine Invertebrate Conservation: Evaluation of Fisheries Over-exploitation Concerns. Am. Zool. 33(6): 551-567.

Keough M.J., Quinn G.P., Kin A. 1993. Correlations between human collecting and intertidal mollusc populations on rocky shores. Conserv. Biol. 7(2): 378-390.

Kingsford M.J., Underwood A.J., Kennelly S.J. 1991. Humans as predators on rocky reefs in New South Wales, Australia. Mar. Ecol. Prog. Ser., 72: 1-14.

Kyle R., Robertson W.D., Birnie S.L. 1997. Subsistence shellfish harvesting in the Maputaland Marine Reserve in northern KwaZulu-Natal, South Africa: Rocky shore organisms. Biol. Conserv. 82: 183-192.

Martins G.M., Jenkins S.R., Hawkins S.J., Neto A.I., Thompson R.C. 2008. Exploitation of rocky intertidal grazers: population status and potential impacts on community structure and functioning. Aquat. Biol. 3: 1-10.

Micheli F., Benedetti Cecchi L., Gambaccini S., Bertocci I., Borsini C., Chato Osio G. Romano F. 2005. Cascading human impacts, marine protected areas and the structure of Mediterranean reef assemblages. Ecol. Monogr. 75: 81-102.

Moreno C.A., Sutherland J.P., Jara H.F. 1984. Man as a predator in the intertidal zone of southern Chile. Oikos 42: 155-160.

Moreno 2001. Community patterns generated by human harvesting on Chilean shores: a review. Aquat. Conserv. Mar. Freshw. Ecosyst. 11: 19-30.

Navarro P.G., Ramírez R., Tuya F., Fernández-Gil C., SánchezJerez P., Haroun R.J. 2005. Hierarchical analysis of spatial distribution patterns of Patellid limpets in the Canary Islands. J. Moll. Stud. 71: 67-73.

Oliva D., Castilla J.C. 1986. The effect of human exclusion on the population-structure of keyhole limpets Fissurella crassa and Fissurella limbata on the coast of central Chile. Mar. Ecol. 7(3): 201-217.

Ortega S. 1987. The effect of human gathering on the size distribution of Siphonaria gigas (Mollusca, Pulmonata) on the Pacific coast of Costa Rica. Veliger, 29(3): 51-255.

Pinnegar J.K., Polunin N.V.C., Francour P., Badalamenti F., Chemello R., Harmelin Vivien M.L., Hereu B., Milazzo M., Zabala M., D’Anna G., Pipitone C. 2000. Trophic cascades in benthic marine ecosystems: lessons for fisheries and protectedarea management. Environ. Conserv. 27(2): 179-200.

Ramírez R., Tuya F., Haroun R. 2009. Efectos potenciales del marisqueo sobre moluscos gasterópodos de interés comercial (Osilinus spp. y Patella spp.) en el Archipiélago Canario. Rev. 
Biol. Mar Oceanogr 44(3): 703-714.

Roberts C.M., Hawkins J.P. 1999. Extinction risk in the sea. Trends Ecol. Evol. 14: 241-246.

Roy K., Collins A.G., Becker B.J., Begovic E., Engle J.M. 2003. Anthropogenic impacts and historical decline in body size of rocky intertidal gastropods in southern California. Ecol. Let. 6: 205-211.

Sagarin R.D., Ambrose R.F., Becker B.J., Engle J.M., Kido J., Lee S.F., Miner C.M., Murray S.N., Raimondi P.T., Richards D., Roe C. 2007. Ecological impacts on the limpet Lottia gigantea populations: human pressure over a broad scale on island and mainland intertidal zones. Mar. Biol. 150: 399-413.

Santos S.R., Hawkins S.J., Montieiro L.R., Alves M., Isidro E.J. 1995. Marine research, resources and conservation in the Azores. Aquat. Conservat. Mar. Freshwat. Ecosyst. 5: 311-354.

Sangil C., Concepción L., Martín-García L., Fernández R. 2011. Explotación pesquera y marisquera, modelo. Marcoplama. Uso, explotación y planificación sostenible de los recursos naturales marinos de la isla de La Palma: interacción del hombre con el medio litoral. Consorcio Insular de la Reserva Mundial de La
Biosfera La Palma. 164 pp + anexes

Siegfried W.R., Hockey P.A.R., Branch G.M. 1994. The exploitation of intertidal and subtidal biotic resources of rocky shores in Chile and South Africa - an overview. Environ. Conserv. 12(4): 303-307.

Thomson R.C., Crowe T.P., Hawkins S.J. 2002. Rocky intertidal communities: past environmental changes, present status and predictions for the next 25 years. Environ. Conserv. 29(2): 168-191.

Underwood A.J. 1993a. The mechanics of spatially replicated sampling programmes to detect environmental impacts in a variable world. Aust. J. Ecol. 18: 99-116.

Underwood A.J. 1993b. Exploitation of species on the rocky coast of New South Wales (Australia) and options for its management. Ocean Coast. Manag. 20: 41-62.

Scient. ed.: M. Gaspar.

Received March 20, 2012. Accepted June 19, 2012.

Published online October 15, 2012. 